\title{
Favourite foods and the fight for country: witchetty grubs and the Southern Pitjantjatjara
}

\author{
Kingsley Palmer
}

\section{Introduction}

Isobel (Sally) White first visited Yalata Lutheran Mission on the edge of the Nullarbor Plain in 1969 with Dr Margaret Kartomi. The following year, having visited Port Augusta and Marree with Mrs L Hercus (now Dr Hercus), she applied to the then Australian Institute of Aboriginal Studies for a grant of $\$ 800$ to spend two months at Yalata to investigate women's status in traditional life. ${ }^{1}$ The grant was approved, with an admonition from the Research Committee to be sure not to visit any men's secret sites with the women. Sally went to Yalata in August 1970, writing in a letter to the Institute that 'they [the Aboriginal women] demand to be taken some miles in the Land Rover for hunting, until I am tired of the sight of dead kangaroos and wombats! These are still the main source of protein in this camp. ${ }^{2}$ The rough conditions she endured in the camp, known as Big Camp or ngura pulka in Pitjantjatjara, are evidenced by her request to the Institute in November 1970 for 'a sum of about $\$ 40$... for repairs to our Department tent, which got chewed by dogs and speared by children in the camp at Yalata'. ${ }^{3}$

Sally was successful in gaining a second grant from the Institute in 1971, again with the stipulated condition that she must not infringe male secrets, to which she replied, 'I resent the gratuitous injunction not to accompany informants to sacred sites. I regard this as a reflection on my own knowledge and intelligence, but even more as a slight on the Aboriginal women themselves'. ${ }^{4}$ It is a reminder of Sally's own struggles as a female anthropologist in a world that remained in the 1970 s still very much the domain of men. But Sally's research was fundamental and immediate. Life in the Yalata camp was tough and at times dangerous but it gave her a close understanding of social relations, cultural activity and the impact of the mission on the people. She was also able to come to an understanding of some of the effects on social relations that had resulted from the involuntary relocations and dispossession that Yalata people had suffered following their forced move from Ooldea. After three weeks fieldwork in August

\footnotetext{
Australian Institute of Aboriginal and Torres Strait Islander Studies file 70/3 ff 3-4.

Ibid., f 32 (letter to F.D. McCarthy 23.8.70).

Ibid., f 39 (letter to F.D. McCarthy 28.11.70).

4. Ibid., f 49 (letter to D.R. Sheppard, Executive Officer. In a hand-written note to Mr Sheppard

Sally wrote, 'This was a very hastily drafted letter — as you realise the last paragraph was not aimed at yourself' (Ibid., f 49).
} 
1971, Sally's tent was burnt down by a drunken man, evidently jealous of Sally's work with his wife and her adoptive 'sisters'. Sally left the field in a hurry, feeling 'defeated and frustrated'.

However, Sally regarded this unfortunate incident as merely a temporary setback. She made numerous subsequent visits to Yalata, collecting materials on life histories (particularly of the women ${ }^{6}$ ), ritual life and daily activities, including hunting and food preparation. ${ }^{7}$ As Sally herself pointed out, the Yalata people were the same people, or their descendants, whom Daisy Bates described in 1938, and with whom Bates had lived for several years in the sand hills of Ooldea. ${ }^{8}$ They were also the people with whom Ronald and Catherine Berndt had worked in 1941 and with whom they had camped as young researchers out of Sydney University. ${ }^{9}$ Ooldea was closed in 1952 and the people dispersed variously north to Indulkana or west to Cundeelee, while a substantial proportion were relocated to Yalata where the Lutheran missionaries were pleased to recruit them to a new mission set up soon after at an old well on a newly declared Reserve in $1953 .^{10}$

\section{Yalata Lutheran Mission and the Maralinga lock-out}

The distance and difficult terrain of the Nullarbor Plain made return to traditional country difficult and, with the onset of the atomic testing program at Maralinga and Emu, such visits were not only discouraged but access barred by British and Australian army personnel. The Lutheran missionaries and the Native Patrol Officer employed by the Woomera Weapons Research Establishment (WRE) worked to limit any visits north (see Brady, this volume). However, the Yalata people's orientation was always north linking cultural and spiritual practices to their homelands in the Great Victoria Desert in both South and Western Australia. When I commenced work at Yalata in 1981, some limited visits had been made to the homelands, by courtesy of a former missionary and Mission Superintendent ${ }_{f}^{11}$ but the expeditions were infrequent and available only to the men. There had been little thought given on the part of the mission authorities or government bureaucrats to a return to what had now become the 'Maralinga Lands', although the bomb testing ended in 1963 and the Range was formally decommissioned in $1968 .{ }^{12}$ By the early 1980s negotiations were already afoot for the Lands to be returned to Aboriginal control. Lack of water, remoteness and distance were cited by government officials and some Yalata staff as reasons for a return to country being impractical.

For Yalata people, residence on the new Reserve was unsatisfactory for a number of reasons. The country was not their own. A few individuals could claim ancestry to the original inhabitants of the region, whom Sally White variously identified as the Wirangu or Gulbinda Bidjandjara. ${ }^{13}$ Most Yalata people identified as Pitjantjatjara,

5. Ibid., f 56 (letter to Professor D.J. Mulvaney 1.9.71).

6. E.g. White 1985.

7. E.g. White 1972, 1977, 1979.

8. Bates 1966.

9. RM Berndt and CH Berndt 1942-45.

10. White 1972; Brady 1987.

11. Palmer 1990.

12. Palmer and Brady 1991: 2 . 
belonging to the southern group of people of that name now widely dispersed across communities in northern South Australia and eastern Western Australia, as well as the Northern Territory. For the majority of Yalata residents, sacred sites for which they were responsible and their associated ritual interest lay to the north of the Trans-Australian railway line (know as the 'Trans Line') and for many their country of origin was as far away as the Marn Ranges or within Western Australia. Cultural attachment to the Yalata Reserve was developed through association with the travels of the Dreaming ancestors, some of whom it was believed roamed south through the country west of the Reserve or to the north of Yalata, one of these being associated with Pidinga (Lake Ifould) some $50 \mathrm{~km}$ north of Yalata. ${ }^{14}$ However, Yalata people felt a huge sense of loss as a result of not being able to access their own country and were concerned for its safety, particularly as they well understood that it was being subjected to violent destructive and long-lasting damage as a result of the atomic testing program. They were also unable to gain access to some traditional foods, including witchetty grubs and red kangaroo, which were either absent or only found in limited quantities in the Reserve.

The climate was also substantially different from that of the deserts north of the Nullarbor Plain. Yalata in winter receives the full force of the westerly gales that sweep in across the Great Australian Bight, making for cold wet conditions. Desert shelters (wiltja), comprising sticks set in the ground and covered by tarpaulins or brush, made for poor protection in wet and windy conditions. In summer the intense heat and choking dust made life difficult, while the water supply at Yalata was a constant source of concern for mission authorities and residents alike. Further north in the sandhill country beyond the Trans Line, conditions were drier and generally warmer, the ground less dusty, the trees more majestic and generous with their shade.

Given this history of dispossession and alienation it is hardly surprising that Sally White found in Yalata a harsh society afflicted with violence and alcohol abuse. But she also found friendship and companionship and a group of caring women who looked after her and protected her. By the early 1980s Yalata's reputation was well formed as a 'difficult' community being described as a 'depressed and broken-down tribal existence' where traditional 'rites [are] gradually diminishing'. ${ }^{15}$ A corrective to this view, commonly held at the time by Department of Aboriginal Affairs staff and seemingly confirmed by the many crises suffered at Yalata, was required. Developing an understanding of how a history of alienation and dispossession, powerlessness and imposed paternalism had affected the Southern Pitjantjatjara was long overdue. Subsequently, with the advent of a more enlightened management at Yalata and the proper implementation of self-determination, Yalata people were able to return to their own country where they developed the settlement that became known as Oak Valley, $150 \mathrm{~km}$ northwest of Maralinga. The details of this event and its implications have been set down elsewhere. ${ }^{16}$ However, during the period of my initial fieldwork at Yalata (1981-82) residents were not only mindful of the desert as an option and an alternative to living at Yalata, but had developed a series of devices to advocate its repossession and benefits.

13. AIATSIS file 70/3., f 39 (letter to F. McCarthy 21.11.70) and $f 66$ (letter to F. McCarthy, 10.3.72).

14. Ibid., $\mathrm{f} 39$.

15. See Palmer 1982: 67.

16. Palmer 1990b: 173-7. 
They did this despite having no immediate expectation that such a return could be realised. $^{17}$

\section{The Indigenous response to the Reserve}

Yalata residents had developed clear views about the country of their adoption, comparing it unfavourably to the desert which they had been forced to leave. The limestone of the Nullarbor fringes, where Yalata is situated, makes for a fine powdery grey soil, dusty in summer and muddy in winter rain. The dust is all pervasive and as a result of the over-exploitation of vegetation, particularly round the settlement, coupled with the repeated use of vehicles to access bush camps, grey dust was everywhere. The Southern Pitjantjatjara refer to the ground at Yalata as parna tjilpi (literally, grey earth or ground). The term tjilpi is also used to mean 'grey' in the sense of becoming old and infirm. Tjilpi is also used as a term of respect and address, rather in the same sense as the term 'elder' is used in some contexts today. However, in conjunction with the term for 'earth' its sense was pejorative, not complimentary. It was believed that the grey earth was responsible for making people's hair grey and a cause of premature ageing, sickness and even death. One man told me in response to a question about Yalata, 'No good. The ground no good, parna tjilpi.' I asked him what he meant and he stated, 'It makes us worry, makes us go grey. It makes us feel no good.'

The country to the north of the Trans Line and beyond, comprising a substantial sand-dune belt and open plains which was the traditional country of many of the Yalata people was regarded with pleasure and described in positive, often eulogistic terms. I remember once passing a particularly fine desert eucalypt ${ }^{18}$ in sandhill country close to the Serpentine Lakes in Western Australia; the women in the Toyota praised its size, its shade and its very existence long after it had passed from view. Such trees, not to be found in the Yalata area, are typical of the desert homelands of many of the older Yalata residents. This country is called parna wiru, which means 'good, fine ground'. The coarse desert sand is not dusty, blows less easily unless heavily disturbed and has few rocks, making for a comfortable camp. Yalata people stated that, unlike the grey earth of the Reserve, the desert sands did not make them unwell, and did not promote premature ageing or grey hair.

While these linguistic devices were elaborate tropes that neatly contrasted present discomfort and its supposed consequences with former comfort and wellbeing, the devices also provided a clear statement of preference: an expression of dissatisfaction with forced residence on another person's country and a desire to return to one's own country. There were other, perhaps less obvious, devices that people used as a means to articulate preference for homeland desert country as well as its produce. Two of these were foods - witchetty grubs and the red kangaroo.

\section{Going for maku and hunting marlu}

Maku ('witchetty grubs', Xyleutes leucomochla) were an important albeit small part of traditional living in the desert. During fieldwork at Oak Valley from 1984 to 1988 a colleague and I were able to observe at first hand how maku were collected, cooked and

17. Palmer 1990a.

18. Probably Eucalyptus papuana or E. gongylocarpa, referred to as para in Pitjantjatjara 
distributed. We were also able to note the value placed on maku by gatherers as well as to record absolute quantities collected.

Maku are the larvae of the Goat Moth (Cossidae) and they are a pale yellow or white colour, although very young ones are sometimes pink. They are found in the roots of a number of shrubs, typically Acacia kempeana (known as ilykuwara in Pitjantjatjara), but they may also be found in the roots of other acacia such as A. muranyana, $A$. victoriae and $A$. ligulata. ${ }^{19}$ As the moth hatches from the root it burrows upward, discards its skin, emerges from the sand and flies away. The skin is known as mirinpa, a term also used for a grub which is close to maturity and therefore tough and not good eating. The discarded skins are eagerly sought by the gatherers as an indication of the possible presence of other grubs beneath the sand.

An expedition to collect maku is termed generally maku-ku (literally, 'for witchetty grubs'), although the term may be qualified by a verb. Typically the expedition involves women and children, although men are not disinclined to participate, even though digging for vegetable food and small animals (including rabbits) is generally regarded as women's work, involving the use of a digging stick (wana). ${ }^{20} \mathrm{~A}$ wana was formerly made from a length of mulga and sharpened at one end, but is now fashioned from a length of steel rod and flattened into a duck's beak at one end by heating in the fire and beating out. Steel rods from windmills are particularly favoured for digging sticks, when available. Some women will cut a digging stick on arrival at the search site, selecting a bush or small tree for the purpose. Before departure from camp (and during the journey) there is animated discussion as to the best place to go for grubs, but on arrival at the agreed destination, people split up into small groups of two or three, a mother taking younger children, the men perhaps going off together. Within a few moments no one is to be seen across the open sandy plains where the acacia bushes grow in abundance.

A woman selects her bush carefully, having due regard for the numbers of discarded skins on the ground. She then begins to excavate the sand, observing the root line by the presence of a low lineal (and barely perceptible) protuberance radiating from the trunk of the bush. While the roots are not deep below the surface (perhaps 150 to $200 \mathrm{~mm}$ on average) the expenditure of energy required to excavate the roots, particularly on a hot day, is not to be underestimated. Many roots have no grubs present or the brood may have hatched, necessitating a move to a new bush identified as promising. Some grubs are eaten raw as they are taken, although most are stored in an old fruit tin or suitable container brought along for the purpose and then they are lightly roasted in the ashes of a small fire, often on site. ${ }^{21}$ If the expedition has been particularly successful, some will be taken back to camp for allocation to kin. The somewhat nutty taste of the grub may be a consequence of the partly digested wood present in the intestines of the grub. ${ }^{22}$

\footnotetext{
19. See Goddard and Kalotas 1995: 58-65.

20. See White 1972: 204.

21. Palmer 1999: 42-3.

22. A.B. Cribb and J.W. Cribb1976: 220.
} 
The numbers of grubs collected indicate that the labour-reward ratio is high. On one occasion $^{23}$ two women working for a total of $1.75 \mathrm{hrs}$ between them collected 59 grubs which were estimated to weigh on average some $5.48 \mathrm{gm}$ each, giving a total yield of just over $323 \mathrm{gm}$. Over half were eaten by children as they were collected, so only a small quantity made it back to the camp. On a second occasion ${ }^{24}$ three adults and four teenage children spent just over an hour and a half to collect 45 grubs, before moving on to a second location where six of the party recovered 37 grubs in a mere $15 \mathrm{~min}-$ utes. Obviously the reward will depend upon the quantities of grubs present in the roots and there is some luck in this. Arriving just after a major hatching will mean a poor harvest. Moreover, the Great Victoria Desert does not appear to have sites where maku are known to be superabundant, as I have noted in desert areas south of Balgo, west of the Stansmore Ranges, Western Australia, where grubs found in the trunks of eucalypts are so plentiful that the area is deemed to have mythological associations to explain the relatively large numbers of grubs to be recovered from the site.

Table 1 is a summary of the data outlined above. It is interesting to note that the two diggers on trip 1 were experienced elder women, while the party in trips $2 \mathrm{a}$ and $2 \mathrm{~b}$ included two men and three teenagers, while one of the women carried a small baby which no doubt impeded her progress. Given a nominal weight for a grub of about 5.5 gm, figures derived from four periods of fieldwork in the region over a twelve month period indicate a per capita annual consumption that could be as high as $1.6 \mathrm{~kg} .{ }^{25}$ Opportunistic gathering is limited to moves to a new camp site (where suitable bushes are plundered for grubs) or other expeditions which in turn depend on the availability of a vehicle. Breakdowns and punctures (with no spare tyre) may also provide the opportunity for gathering activities while passengers fill in their time awaiting rescue. However, it is likely that traditionally, as people fanned out across the countryside daily in order to secure a livelihood, maku were consumed in small quantities, although they may (as today) have been consumed more by children than by adults.

\section{Table 1: Maku yields on three occasions}

\begin{tabular}{|l|c|c|c|c|c|}
\hline & Diggers & Total time & Nos grubs & Aggregate weight & Per hr yield \\
\hline Trip 1 & 2 & $1.75 \mathrm{hrs}$ & 59 & $323 \mathrm{gm}$ & $184.6 \mathrm{gm}$ \\
\hline Trip 2a & 7 & $10.5 \mathrm{hrs}$ & 45 & $247 \mathrm{gm}$ & $23.5 \mathrm{gm}$ \\
\hline Trip 2b & 6 & $1.5 \mathrm{hrs}$ & 37 & $203 \mathrm{gm}$ & $135.3 \mathrm{gm}$ \\
\hline
\end{tabular}

The time and energy required to recover the grubs could only be justified if the source for the food (the acacia bushes) was at hand. Nevertheless, witchetty grubs are high in energy, providing more kilojoules than wild honey (sugarbag), ${ }^{26}$ approximately $80 \%$ of the protein of a kangaroo ${ }^{27}$ but with between $20 \%$ to $47 \%$ fat. Peile ${ }^{28}$ notes of the

23. Maralinga Lands, May 1987.

24. Maralinga Lands, November 1987

25. Palmer and Brady 1991: 41.

26. Brand Miller, James and Maggiore, 1997: 226, 236.

27. Ibid: 210.

28. Peile 1997: 18-19. 
Kukatja who occupied the northern parts of the Great Sandy Desert, south of the former Pallotine Mission of Balgo, Western Australia, that witchetty grubs were an important part of the diet of both babies and children. ${ }^{29}$

Expeditions to collected maku were often combined with hunting activity, particularly as this gave any men in the party the opportunity to contribute to the food supply. The Maralinga Lands had long been regarded as providing a plentiful supply of meat, partly because they were less hunted than the Reserve, but also because the marlu or red kangaroo (Macropus rufus) was found in abundance in the desert and was much preferred to the kulpirpa or grey kangaroo (Macropus fuliginosus) which was more common at Yalata. Reoccupation of the Maralinga Lands provided ample opportunity for hunting which was pursued with great enthusiasm, particularly by the younger men. Hunting expeditions were carried out from the main camp, in whatever vehicle was available, although a four-wheel drive was preferred, as this gave greater flexibility and access to the sandhill country favoured by the red kangaroo. However, Holdens and Ford Falcons were urged off the tracks and into the bush, and people often shot opportunistically when travelling the long road from Watson (on the Trans Line) to the camp at Oak Valley.

Quantities of meat taken and eaten were considerable. During field work in 1987 and 1988 a colleague and I calculated that in excess of 800 kangaroos were taken in a year, and recorded an average daily consumption of $549 \mathrm{gm} .{ }^{30}$ These calculations made allowance for wastage, non-edible tissue and portions wasted or fed to the dogs. Eating half a kilo of kangaroo meat a day represents a significant intake of protein. Residents were eager to exploit this resource, which may have been available in larger quantities than traditionally, due to prolonged periods of non-exploitation as well as the availability of vehicles and rifles. Access to the meat of the red kangaroo was seen as one of the benefits of desert living in contrast to the fact that it was generally not available at Yalata. Certainly the meat constituted an important part of both the diet and hunting activity of outstation residents while the cooking and subsequent distribution were important and frequent social activities in the life of the camp. When kangaroo was brought in, most, if not all, received a portion, and this sharing served to confirm a sense of community amongst residents of the newly established settlement.

\section{Maku and marlu as metaphor}

Yalata was largely devoid of both marlu and maku as well as a number of other desert species. The grey earth of Yalata does not support the acacia favoured by the Goat Moth to lay its eggs which produce the larvae. However, these are found in abundance north of the Trans Line in the desert country. The red kangaroo is found only to the north of Yalata, requiring a substantial journey of perhaps 25 to $30 \mathrm{~km}$ to reach its habitat, where it was still not common. North of the Trans Line, on the plains of the Great Victoria Desert, it is found in greater numbers and the desert was considered its true home. Consequently, during their enforced stay at Yalata the Southern Pitjantjatjara ate no witchetty grubs and few red kangaroo.

29. See also Tindale 1952: 60.

30. Palmer and Brady 1991: 37-38; Palmer and Brady 1988. 
After a period of fieldwork at Yalata in 1981, plans were made for a colleague and I to take a party of Yalata residents back to their traditional country to visit sites and inspect country. For the first time such an expedition was to include women. Seats were limited and in strong demand. Not all who wished to travel could be accommodated. However, one request from those remaining rang in our ears as we departed, 'Bring us back some maku'. We were also told that once in the 'spinifex', as the desert north of the Trans Line was popularly called, red kangaroo would be plentiful. Indeed, once back in the spinifex country maku stops were frequent and most days we ate marlu. On subsequent trips, the collection of grubs and hunting of red kangaroo were important components of any visit to the clean sands of the desert. Back at Yalata, and as discussions developed about the return of the Maralinga Lands and, more importantly, a return to what was to become Oak Valley, the importance, significance and culinary merits of maku and marlu were a repeated subject for discussion and debate. Living back in the desert, so it was prophetically argued, would provide easy access to plentiful supplies of both marlu and maku. The grubs were characterised as being nutritious (which they were) and could also be used as a paste, when raw, rubbed into the skin and hair to make people shiny and healthy ${ }^{31}$, in contrast to the sickly pallor that characterised living at Yalata with the grey dust. Red kangaroo, easy to obtain in the spinifex, made people strong and had a softer, tastier meat than the grey kangaroo. Marlu is a significant mythological character for the Southern Pitjantjatjara, being surrounded by a complex of narratives and cultural practices dictating how it should be prepared for cooking, cooked and allocated, ${ }^{32}$ and it was consider the proper meat of the Southern Pitjantjatjara. Few grubs actually made it the considerable distance back to Yalata and most kangaroo meat was only fit for the dogs after the long journey. However, both had acquired a significance far beyond any value attributable to their nutritional content, particularly in the presence of a reasonable supply of foods in the community store.

In 1972 Sally White published a short paper in Mankind about hunting dogs at Yalata. ${ }^{33}$ She describes how the Yalata people hunted three principal animals: the wombat (Lasiorhinus latifrons), the grey kangaroo (Macropus fuliginosus) and the red kangaroo (M. rufus). Dogs were used to hunt kangaroo and were found to be more reliable than the (evidently) inaccurate rifles available at that time. Wombats were either shot or clubbed. White asks why the hunting dogs should be so valued, particularly when they ate a substantial proportion of the meat they hunted. ${ }^{34}$ She answers this in part by stating that the adoption of European dogs to replace the native dingo, a process observed by the Berndts in 1942, ensured success in hunting and a relatively plentiful supply of 'wild protein' independent of the missionaries and Yalata. Dogs were important because they helped secure highly prized meat which was valued because it could be obtained without obligation or reliance on the missionaries or government. The process of using dogs to obtain meat constituted a statement and act of independence and was also an expression of a disinclination to accept the rule, control and domination of the mission.

31. M Brady, pers. comm. 1999.

32. Palmer 1999: 31-34.

33. White 1972.

34. Ibid.: 202. 
By the time I worked at Yalata a decade later, the people had gained greater autonomy and the missionaries were no longer present to issue rations and control people's lives. However, Yalata people continued to use food as a metaphor to promote their preferred environment and to distinguish present occupation of the Reserve from their aspirations to reoccupy their desert homelands. What White does not mention was the Yalata people's decided preference for red kangaroo (marlu) over the grey (kulpirpa). Yalata people, in confirming a preference for marlu, stated that it was the 'proper' meat for desert dwellers; it was a fundamental part of their culture, way of life and living. Like the maku it also served to remind them of the desert and their former lifestyle. Both had become a metaphor for the spinifex country to the north that people longed to repossess. Both had become synonymous with an ideology that rejected missions and government settlements while embracing a return to homelands, clean sand and the spinifex which many continued to regard as their true and proper home. While both species were potentially valuable sources of nutrition, at Yalata their symbolic value far outweighed their economic value.

In slightly different ways both the marlu and the maku had acquired a value for the Yalata people through their representation of a culture and a way of life which the mission had sought to displace. The value of the marlu and the maku lay not only in the fact that they were good to eat, but also in their attributions; they were good to think with too.

\section{Conclusion}

The history of the struggle of the Southern Pitjantjatjara to regain their homelands has been marked by successive frustrations and setbacks occasioned by government interference and missionary zeal. They were a people heavily affected by the building of the Trans Line, completed in 1917.35 They were abandoned by a mission at Ooldea that had fostered their dependence, and relocated to the Yalata Reserve to suit the South Australian government and the expansionist policies of the Lutheran missionaries. Locked out of their country by policies and procedures that made it virtually impossible for them to return to their homelands until the early 1980s, the development of an outstation was still considered an absurdity by many when I undertook my field work at Yalata at that time. However, the Southern Pitjantjatjara retained their language and cultural practices to a degree many would have considered impossible. Their links with the spinifex were articulated, not only through ritual and song (which was vital and vigorous in the 1980s), but in more subtle ways where cultural and territorial preferences were framed through reference to phenomena that were quintessentially of the spinifex and their own territory. The return to the clean sands of the parna wiru of the desert provided people with the opportunity to exchange symbols of what had been a lost inheritance for economic certainty.

Kingsley Palmer is an anthropologist based at the Australian Institute of Aboriginal and Torres Strait Islander Studies, of which he is Deputy Principal. 


\section{References}

Bates, D. 1966 (first published 1938) The passing of the Aborigines. Heinemann, Melbourne.

Berndt, R. and Berndt, C. 1942-45. 'A preliminary report of fieldwork in the Ooldea region, western South Australia', Oceania 12(4), 13(1-4), 14(1-4), 15(1-3).

Brady, M. 1987. 'Leaving the spinifex: the impact of rations, missions, and the atomic tests on the Southern Pitjantjatjara'. Records of the South Australian Museum, 20: 3545.

Brand Miller, J. James, K. and Maggiore, P. 1993. Tables of composition of Australian Aboriginal foods. AIATSIS, Canberra.

Cribb, A.B \& Cribb, J.W 1976. Wild food in Australia. Fontana Collins, Sydney.

Goddard, C. and Kalotas, A. 1995. Punu: Yankunytjatjara plant use. I.A.D. Press, Alice Springs.

Palmer, K. 1982. 'Grey earth and clean sand. Yalata Aborigines and their homelands'. Unpublished report, Flinders University, South Australia.

Palmer, K. 1990a. 'Dealing with the legacy of the past: Aborigines and the atomic testing in South Australia'. Aboriginal History, 14(1-2): 197-207.

Palmer K. 1990b. 'Government policy and Aboriginal aspirations: self-management at Yalata', in R. Tonkinson and M. Howard (eds) Going it alone? pp 164-183. Aboriginal Studies Press, Canberra.

Palmer K. 1999. Swinging the billy: Indigenous and other styles of Australian bush cooking. AIATSIS, Canberra.

Palmer, K. and Brady, M. , 1988. 'The diet and lifestyle of Aborigines in the Maralinga Region, South Australia: a report prepared for Maralinga Tjarutja as part of the Maralinga Rehabilitation Studies.' Unpublished manuscript, Canberra.

Palmer, K. and Brady, M. 1990. 'Diet and lifestyle of Aborigines in the vicinity of the atomic test sites in South Australia'. Paper presented to the $6^{\text {th }}$ Conference on Hunting and Gathering Societies, Alaska, 1990.

Palmer, K. and Brady, M. 1991. Diet and dust in the desert: an Aboriginal community, Maralinga Lands, South Australia, AIATSIS, Canberra.

Peile, A.R. 1997. Body and soul: an Aboriginal view, (ed.) P Bindon. Hesperian Press, Perth.

Tindale, N.B. 1952. 'Some Australian Cossidae including Witjiti ( witchetty) grub'. Transactions of the Royal Society of South Australia, 76: 56-65.

White, I.M. 1985. 'Mangkatina: woman of the desert', in I. White, D. Barwick and B. Meehan (eds) Fighters and singers. The lives of some Australian Aboriginal women, pp 214-226. George Allen \& Unwin, Sydney.

White, I.M. 1972. 'Hunting Dogs at Yalata', Mankind 8: 201-205.

White, I.M. 1977. 'The natives live well', in Kuper, J. (ed.) The anthropologists' cookbook, pp 216-220. Routledge and Kegan Paul, London.

White, I.M. 1992. 'Australian Aboriginal myth', in Larrington, C. (ed.) The feminist companion to mythology, pp 251-268. Pandora Press, London.

White, I.M. 1979. 'Rain ceremony at Yalata', Canberra Anthropology, 2(2): 94-103. 